\title{
Effect of in vitro exposure time on comet assay results
}

\author{
Kaoru Sekihashi ${ }^{1,3}$, Hiromi Saitoh ${ }^{1,4}$, Ayako Saga ${ }^{1}$, Kazushige Hori ${ }^{2}$, \\ Munehiro Nakagawa ${ }^{2}$, Makoto Miyagawa ${ }^{2}$ and Yu F. Sasaki ${ }^{1 *}$ \\ ${ }^{1}$ Hachinohe National College of Technology \\ Tamonoki Uwanotai 16-1, Hachinohe, Aomori 039-1192, Japan \\ ${ }^{2}$ Mitsubishi Chemical Safety Institute Ltd. Kashima Laboratory, Genetic Toxicology Group \\ Sunayama 14, Hasaki-machi, Kashima-gun, Ibaraki 314-0255, Japan
}

\begin{abstract}
Summary
Some mutagens are inactivated rapidly by components included in culture media, especially by serum. Long incubation periods may not be appropriate for the comet assay because DNA lesions may be repaired during the time that mutagens are inactivated, leading to false negative results. We questioned how the exposure period of Chinese hamster ovary cells to 8 unstable mutagens affected outcome of the assay.

Although the longest biological half-life of the test mutagens was $1.98 \mathrm{~h}$, four were positive following $0.5-24 \mathrm{~h}$ incubations while other four were positive only when the incubation period was $\leq 4 \mathrm{~h}$, suggesting that the DNA damage was repaired and the mutagens were inactivated. The rapid inactivation of mutagens in the medium did not affect whether the outcome of the comet assay was positive or negative when cells were exposed for 1-4 h. Based on these results, we concluded that long exposure should not be employed for the compounds that are unstable in culture media, and appropriate incubation time should be determined for them individually.
\end{abstract}

Keywords: in vitro comet assay, exposure period, inactivation, biological half-life

\section{Introduction}

Because exposure period is an important factor affecting the outcomes of in vitro genotoxicity test, extensive studies to determine choice appropriate exposure periods in the TK mutation (Moore et al., 2000) and chromosome aberration tests (Galloway, 2000) have been conducted. The alkaline $(\mathrm{pH}>13)$ comet assay introduced by Singh et al. (1988) is a rapid and sensitive procedure for quantitating DNA lesions in mammalian cells. It detects not only single strand breaks but also alkali-labile sites, DNA crosslinking, and incomplete excision repair

\footnotetext{
*E-mail: yfsasaki-c@hachinohe-ct.ac.jp

Present address: ${ }^{3}$ Toxicology Laboratory, Taisho Pharmaceutical Co., Ltd., Yoshino-cho 1-403, Saitama-shi, Saitama 330-8530, Japan

${ }^{4}$ Mitsubishi Chemical Safety Institute Ltd. Kashima Laboratory, Genetic Toxicology Group, Sunayama 14, Hasaki-machi, Kashima-gun, Ibaraki 314-0255, Japan

Received: March 13, 2003, accepted: August 7, 2003

(C) Japanese Environmental Mutagen Society
}

sites (Singh et al., 1988; Fairbairn et al., 1995). Now, the comet assay is used widely to detect chemical genotoxicity in vitro and in vivo, this assay was discussed in the 1999 International Workshop on Genotoxicity Test Procedures Workgroup held in Washington, D.C., in which consensus was reached on many important aspects of the comet assay protocol. To detect chemical genotoxicity in vitro, an appropriate exposure period was considered to be 3-6 $\mathrm{h}$ in the presence or absence of a metabolic activation system (Tice et al., 2000).

Some mutagens are inactivated rapidly by components included in culture media especially by serum (Jensen et al., 1977). When assessing a chemical that is unstable in culture media with the comet assay, a long exposure period would not be appropriate because the initial DNA lesions would be repaired and new ones would not be formed after inactivation of chemical, leading to false negative results. In this study, therefore, we questioned whether the exposure period to unstable chemicals affects the outcome of the assay. 


\section{Materials and Methods}

\section{Chemicals, cells, and medium}

$N$-methyl- $N$ 'nitro- $N$-nitrosoguanidine (MNNG: CAS 70 25-7), $N$-ethyl- $N$ '-nitro- $N$-nitrosoguanidine (ENNG: CAS 63885-23-4), methyl methanesulfonate (MMS: CAS 6627-3), and ethyl methanesulfonate (EMS: CAS 62-50-0) were purchased from Sigma Chemicals Inc., St. Louis, MO (U.S.A.). Methyl nitrosourea (MNU: CAS 684-93-5) and ethyl nitrosourea (ENU: CAS 759-73-9) were purchased from Nacalai Tesque, Inc., Kyoto (Japan). 4Nitroquinoline-1-oxide (4NQO: CAS 56-57-5) and hydrogen peroxide $\left(\mathrm{H}_{2} \mathrm{O}_{2}\right.$ : CAS 7722-84-1) were purchased from Wako Pure Chemical Industries, Ltd., Osaka (Japan). The chemicals were dissolved in Hanks' balanced salt solution ( $\mathrm{pH}$ 7.0) immediately before use. Regular (GP-42) and low melting point (LGT) agarose were purchased from Nacalai Tesque, Inc., and diluted to $0.75 \%$ in physiological saline.

Chinese hamster ovary ( $\mathrm{CHO} \mathrm{K} 1$ ) cells, obtained originally from American Type Culture Collection and cloned, were grown in Ham's F12 medium (Nissui Pharmaceutical Inc., Tokyo, Japan) supplemented with $10 \%$ fetal bovine serum (FBS) (Armour Pharmaceutical Company, Kentakee, U.S.A., Lot No. D84812) at $37{ }^{\circ} \mathrm{C}$ with $5 \% \mathrm{CO}_{2}$.

\section{Treatment}

To study the effects of exposure periods, we treated logarithmic growth phase $\mathrm{CHO}$ cells $\left(1 \times 10^{6}\right.$ cells $/ \mathrm{mL}$ treatment medium) with each chemical at $37^{\circ} \mathrm{C}$ for $30 \mathrm{~min}-24$ $\mathrm{h}$ in fresh culture medium containing FBS. Cells were sampled immediately after treatment as described below, and the percentage of viable cells was measured by the trypan blue exclusion test. The highest treatment concentration was chosen as the concentration at which cell viability after $24 \mathrm{~h}$ treatment was not lower than $70 \%$.

To detect the biological half-life of each mutagen in the culture media, we incubated them at $37^{\circ} \mathrm{C}$ for $0-4$ hours in Ham's F12 medium containing 10\% FBS. The concentration was the highest concentration used for the study of the effects of exposure periods. Cells were exposed for 1 $\mathrm{h}$ to the medium in which each mutagen had been incubated and were sampled immediately after exposure, as described below.

\section{Comet assay}

Seventy five $\mu \mathrm{L}$ of $1 \%$ agarose GP-42 (Nakalai Tesque, Inc., Kyoto, Japan) was quickly layered on a slide (Matsunami Glass Ind., Ltd., Osaka, Japan) and covered with another slide glass. Treated cells were suspended in $1 \%$ agarose-LGT (Nakalai Tesque, Inc.) and $75 \mu \mathrm{L}$ of cell suspension $\left(5 \times 10^{5}\right.$ cells $\left./ 75 \mu \mathrm{L}\right)$ was quickly layered at the same manner after removing the slide glass.
Finally, $75 \mu \mathrm{L}$ of $1 \%$ agarose GP-42 was quickly laid on again. The slide were lysed immediately in a solution $(\mathrm{pH}$ 10) of $2.5 \mathrm{M} \mathrm{NaCl}, 100 \mathrm{mM} \mathrm{Na} 2 \mathrm{EDTA}, 10 \mathrm{mM}$ Trizma, $1 \%$ sarkosyl, $10 \%$ DMSO, and $1 \%$ Triton X-100 at $4{ }^{\circ} \mathrm{C}$ for 60 min (Singh et al., 1988).

The slides were placed on a horizontal gel electrophoresis platform, and covered with an alkaline solution made up of $300 \mathrm{mM} \mathrm{NaOH}$ and $1 \mathrm{mM} \mathrm{Na} \mathrm{NDDA}_{2}$ ( $\left.\mathrm{pH}>13\right)$. The slides were left in the solution for $20 \mathrm{~min}$ to allow the unwinding of the DNA and expression of alkali-labile sites. The power supply was set at $25 \mathrm{~V}$ and $250 \mathrm{~mA}$. The DNA was electrophoresed for $20 \mathrm{~min}$ and the slides were rinsed with $400 \mathrm{mM}$ Trizma $(\mathrm{pH} \mathrm{7.5)}$ to neutralize the excess alkali. Each slide was stained with $50 \mu \mathrm{L}$ of 20 $\mu \mathrm{g} / \mathrm{mL}$ ethidium bromide (Wako Pure Chemical Industries, Ltd.) and covered with a coverslip.

Cells on one slide were photographed (black and white 400 ASA Fuji film) as seen with the aid of a fluorescence microscope (Olympus at $200 \times$ magnification) equipped with an excitation filter of 515-560 $\mathrm{nm}$ and a barrier filter of $590 \mathrm{~nm}$. The length of the comet (migration) was measured for fifty cells per treatment group. The effect of chemical treatment on migration was analyzed using ANOVA and the Dunnett test.

To calculate biological half-life, the relative induced migration was obtained as the percentage of net migration value after each incubation period for that after $0 \mathrm{~h}$-incubation. The approximation polynomial of relative induced migrations was obtained and the biological half-life was calculated by solving the equation obtained from the approximation polynomial.

\section{Results}

Fig. 1 shows the exposure period-response curves for $\mathrm{CHO}$ cells exposed to each mutagen. With any treatment condition, relative cell viability was over $70 \%$ (data not shown). Fig. 2 shows the results of exposure for $1 \mathrm{~h}$ to culture medium in which mutagen had been incubated for 0-4 h. Each symbol shows relative induced migration value. Broken curves are approximation curves that were calculated from approximation polynomials based on relative induced migration values.

ENU exposure yielded DNA damage after $0.5-1 \mathrm{~h}$ at 50 $-400 \mu \mathrm{g} / \mathrm{mL}$. DNA migration returned to control levels after exposure for $24 \mathrm{~h}$. The biological half-life of ENU in the culture medium was calculated to be $1.01 \mathrm{~h}$.

MNU exposure yielded DNA damage after $0.5-24 \mathrm{~h}$ at $25-100 \mu \mathrm{g} / \mathrm{mL}$, with the damage peaking at $2 \mathrm{~h}$. The biological half-life of MNU in the culture medium was $1.07 \mathrm{~h}$.

DNA damage induced by EMS at $50-200 \mu \mathrm{g} / \mathrm{mL}$ peaked at 2-4 h. Exposure to the highest concentration for EMS exposure for $1 \mathrm{~h}$ led to a positive response. The biological half-life of EMS in culture medium was calculated to be $1.98 \mathrm{~h}$. 

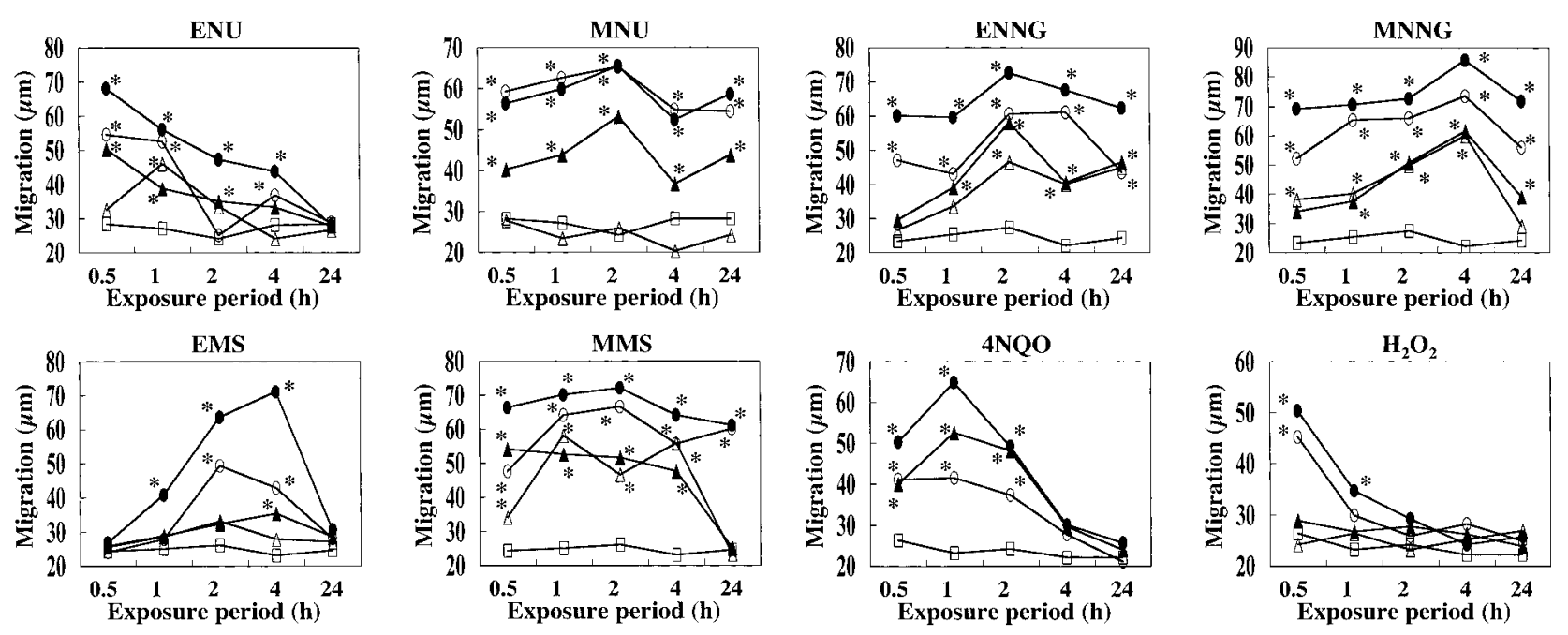

Fig. 1 Comet assay of DNA taken from CHO cells exposed for various time periods to 8 mutagens. CHO cells were treated for $0.5-24 \mathrm{~h}$ with

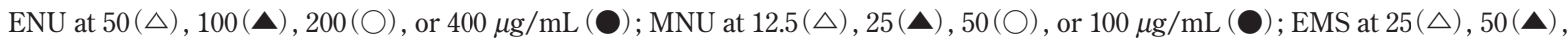
$100(\bigcirc)$, or $200 \mu \mathrm{g} / \mathrm{mL}(\bigcirc)$; MMS at $5(\triangle), 10(\boldsymbol{\Delta}), 20(\bigcirc)$, or $40 \mu \mathrm{g} / \mathrm{mL}(\bullet)$; ENNG $2.5(\triangle), 5(\boldsymbol{\Delta}), 10(\bigcirc)$, or $20 \mu \mathrm{g} / \mathrm{mL}(\mathbf{\bullet})$; MNNG at $0.31(\triangle), 0.63(\mathbf{\Delta}), 1.25(\bigcirc)$, or $2.5 \mu \mathrm{g} / \mathrm{mL}(\bullet) ; 4 \mathrm{NQO}$ at $0.048(\boldsymbol{\Delta}), 0.095(\bigcirc)$, or $0.19 \mu \mathrm{g} / \mathrm{mL}(\mathbf{\bullet}) ; \mathrm{H}_{2} \mathrm{O}_{2}$ at $0.75(\triangle), 1.5$ $(\boldsymbol{\Lambda}), 3(\bigcirc)$, or $6 \mu \mathrm{g} / \mathrm{mL}(\bigcirc)$. The symbol $\square$ indicates control. Significant difference: ${ }^{*} \mathrm{p}<0.05$.
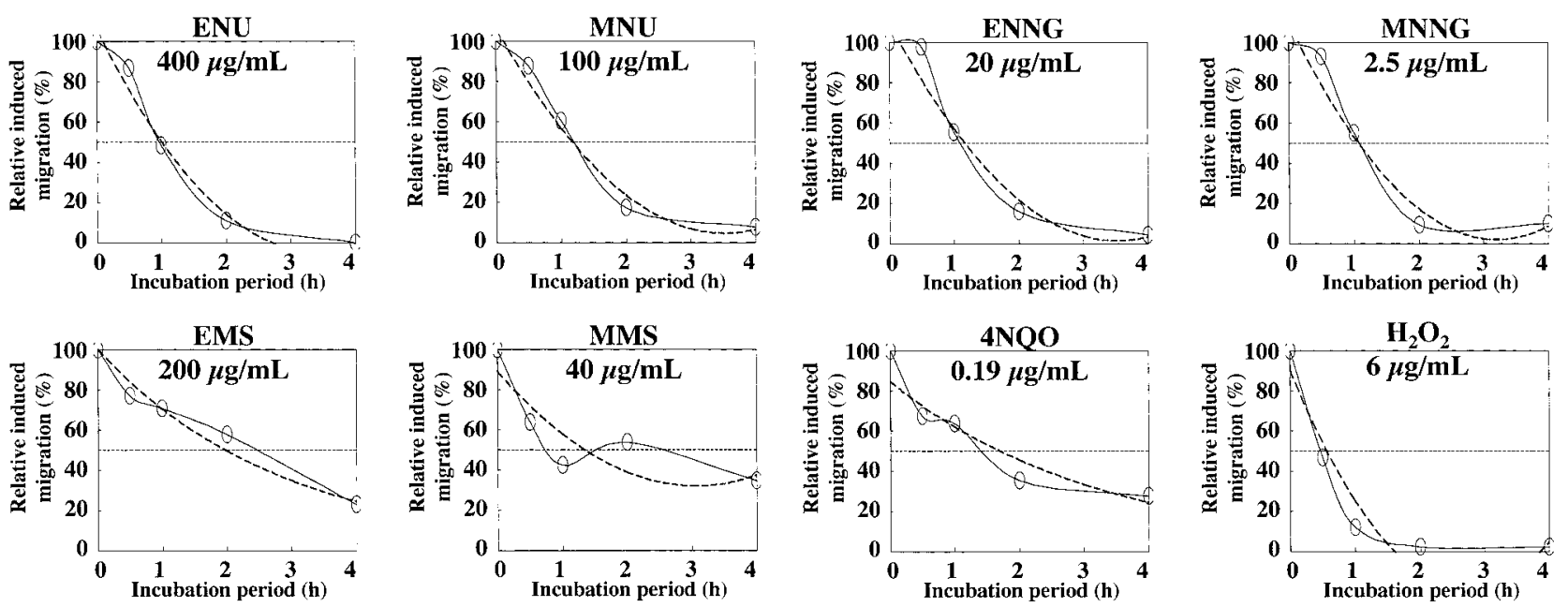

Fig. 2 Comet assay of DNA taken from $\mathrm{CHO}$ cells exposed to 8 mutagens that were preincubated in culture medium containing FBS for 0-4 $\mathrm{h}$. $\mathrm{CHO}$ cells were exposed for $1 \mathrm{~h}$ to culture medium in which mutagens at the concentrations shown in the figures had been incubated for $0-4 \mathrm{~h}$. Each symbol shows relative induced migration value. Curves shown as broken lines are approximation polynomials calculated based on relative induced migration values.

Exposure to high concentrations of MMS for $0.5-24 \mathrm{~h}$ led to positive responses while exposure to the low concentration did not, even after $24 \mathrm{~h}$. The biological half-life of MMS in the culture medium was calculated to be 1.33 h.

ENNG at $2.5-20 \mu \mathrm{g} / \mathrm{mL}$ led to positive responses. DNA damage induced by ENNG at $20 \mu \mathrm{g} / \mathrm{mL}$ peaked following exposure for $2 \mathrm{~h}$ and then decreased. Its biological half-life of ENNG in the culture medium was calculated to be $1.11 \mathrm{~h}$.

DNA damage induced by MNNG peaked at $4 \mathrm{~h}$ at $0.31-$ $2.5 \mu \mathrm{g} / \mathrm{mL}$. DNA damage was not evident following expo- sure for $24 \mathrm{~h}$ at $0.31 \mu \mathrm{g} / \mathrm{mL}$. The biological half-life of MNNG in the culture medium was calculated to be $0.96 \mathrm{~h}$.

DNA damage induced by $4 \mathrm{NQO}$ at $0.048-0.75 \mu \mathrm{g} / \mathrm{mL}$ peaked following exposure for $1 \mathrm{~h}$ and then decreased. The biological half-life of $4 \mathrm{NQO}$ in the culture medium was calculated to be $1.74 \mathrm{~h}$.

CHO cell exposure to $\mathrm{H}_{2} \mathrm{O}_{2}$ for $30 \mathrm{~min}$ at 3 and $6 \mu \mathrm{g} / \mathrm{mL}$ led to positive responses. DNA damage had decreased with exposure time starting at $1 \mathrm{~h}$ or more. On the other hand, $\mathrm{CHO}$ cell exposure to $\mathrm{H}_{2} \mathrm{O}_{2}$ at 0.75 and $1.5 \mu \mathrm{g} / \mathrm{mL}$ did not lead to positive responses. The biological half-life of $\mathrm{H}_{2} \mathrm{O}_{2}$ in the culture medium was calculated to be $0.65 \mathrm{~h}$. 


\section{Discussion}

Among the studied mutagens, EMS showed the longest biological half-life, $1.98 \mathrm{~h}$. Thus, the mutagens were inactivated rapidly in the medium, which contained FBS. The relationship of comet assay results to treatment period was divided into two. DNA damage induced by ENU, EMS, $4 \mathrm{NQO}$, and $\mathrm{H}_{2} \mathrm{O}_{2}$ decreased with exposure period and returned to control level following $24 \mathrm{~h}$ treatment. Considering that their biological half-lives of the mutagens were less than $2 \mathrm{~h}$, it is likely that the induced DNA damage was repaired between mutagen inactivation and the sampling at $24 \mathrm{~h}$. Although $\mathrm{H}_{2} \mathrm{O}_{2}$ produces oxidative DNA-strand breaks, most are repaired within 15 min (McKelvey-Martin et al., 1993), but in the present study $\mathrm{H}_{2} \mathrm{O}_{2}$ was positive after $0.5-4 \mathrm{~h}$ exposure. That coincides with the finding by Visvardis et al. (1997) in lymphocytes, in which DNA damage persist for over $2 \mathrm{~h}$ following incubation with $\mathrm{H}_{2} \mathrm{O}_{2}$. On the other hand, DNA damage induced by MNU, ENNG, MNNG, and MMS did not decrease greatly and was detected following $24 \mathrm{~h}$ of treatment. Thus, the DNA damage they induced tended to be difficult to be repaired.

Jensen et al. (1977) reported that the biological halflives of $1 \mathrm{mg} / \mathrm{mL}$ MNU and $3 \mu \mathrm{g} / \mathrm{mL} 4 \mathrm{NQO}$ were, respectively, $8 \mathrm{~min}$ and $67 \mathrm{~h}$ in culture medium containing $15 \%$ FBS. Which components of media inactivate mutagens is not known and presumably, the biological half-lives of mutagens would differ in different media. In spite of such differences the fact that mutagens are inactivated in media is important to the choice of treatment period in the comet assay. Our results suggest that rapid inactivation of mutagens does not affect whether the outcome of the assay is positive or negative when cells are exposed for up to $4 \mathrm{~h}$. Despite this, even after exposing human hepatoma HepG2 cells for $96 \mathrm{~h}$ to four known promutagens (cyclophosphamide, benzo $[a]$ pyrene, dimethylbenz $[a]$ anthracene, and 2-acetylaminofluorene), Yusuf et al. (2000) noted positive effects. It should be also taken into consideration that repair processes could be damaged by compounds that suppress DNA repair and that cells could experience growth cessation or cell cycle arrest after exposure to DNA damaging agents (Smith and Fornace, 1996). However, long exposure periods should not be employed for compounds that are unstable in culture media, and appropriate incubation times should be determined for them individually.

\section{References}

Fairbairn, D.W., P.L. Olive and K.L. O’Neill (1995) The comet assay: a comprehensive review, Mutat. Res., 339, 37-59.

Galloway, S.M. (2000) Cytotoxic and chromosome aberrations in vitro: experience in industry and the case for an upper limit on toxicity in the aberration assay, Environ. Mol. Mutagen., 35, 191-201.

Jensen, E.M., R.J. La Polla, P.E. Kirby and S.R. Haworth (1977) In vitro studies of chemical mutagens and carcinogens. I. Stability studies in cell culture medium, J. Natl. Cancer Inst., 59, 941-944.

McKelvey-Martin, V.J., M.H.L. Green, P. Schmezer, B.L. Pool-Zobel, M.P. De Meo and A. Collins (1993) The single cell gel electrophoresis assay comet assay: An European review, Mutat. Res., 288, 47-63.

Moore, M.M., M. Honma, J. Clements, T. Awogi, G. Bolcsfoldi, J. Cole, B. Gollapudi, K. Harrington-Brock, A. Mitchell, W. Muster, B. Myhr, M. O’Donovan, M.C. Ouldelhkim, R. San, H. Shimada and L.F, Stankowski Jr. (2000) Mouse lymphoma thymidine kinase locus gene mutation assay: International Workshop on Genotoxicity Test Procedures Workgroup Report, Environ. Mol. Mutagen., 35, 185-190.

Singh, N.P., M.T. McCoy, R.R. Tice and E.L. Schneider (1988) A simple technique for quantitation of low levels of DNA damage in individual cells, Exp. Cell Res., 175, 184-191.

Smith, M. and A. Fornace Jr. (1996) Mammalian DNA damageinducible genes associated with groth arrest and apoptosis, Mutat. Res., 340, 109-124.

Tice, R.R., E. Agurell, D. Anderson, B. Burlinson, A. Hartmann, H. Kobayashi, Y. Miyamae, E. Rojas, J.C. Ryu and Y.F. Sasaki (2000) Single cell gel/comet assay: guidelines for in vitro and in vivo genetic toxicology testing, Environ. Mol. Mutagen., 35, 206-221.

Visvardis, E.-E., A.M. Tassiou and S.M. Piperakis (1997) Study of DNA damage induction and repair capacity of fresh and cryopreserved lymphocytes exposed to $\mathrm{H}_{2} \mathrm{O}_{2}$ and $\gamma$-irradiation with the alkaline comet assay, Mutat. Res., 383, 71-80.

Yusuf, A.T., L. Vian, R. Sabatier and J.-P. Cano (2000) In vitro detection of indirect-acting genotoxins in the comet assay using Hep G2 cells, Mutat. Res., 468, 227-234. 